\title{
Economic resilience and the state: A global panel analysis
}

\section{Cristian-Valeriu Paun (D), Radu-Cristian Musetescu (D), Radu Isaic (D), Gheorghe Cosmin Manea ${ }^{\mathbb{D}}$, Hezi-Aviram Shayb}

Bucharest University of Economic Studies,

Piața Romană 6, București 010374, Romania

cristian.paun@rei.ase.ro; radu.musetescu@rei.ase.ro; isaicradu@yahoo.com; maneacosmin37@gmail.com; shaybhezi@gmail.com

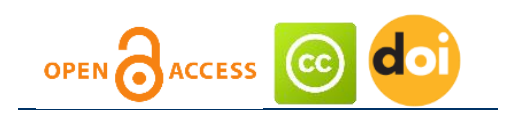

Article history:

Received: June 11, 2021

1st Revision: October 26,

2021

Accepted: November 24, 2021

\section{JEL classification: \\ F10 \\ F44 \\ F43 \\ G15 \\ H12}

\section{DOI:}

10.14254/jems.2021.6-2.3

\begin{abstract}
Modern economies are disturbed by recessions that have become more and more globalized, much contagious between countries and regions, and with higher negative impacts during recessions. In this dynamic context, the recovery after the recession is essential to prepare the economy for the next business cycle. Understanding these business cycles (their causes and impact) is fundamental for public policies that should avoid being pro-cyclical and adding more vulnerabilities to the existing economic downturns. Economic resilience is now a key concept in the economic literature. It refers to the capacity of the economy to recover after a recession. This paper aims to explore the relationship between the dimension of the state and the resilience of the economic system by using global panel data. The study includes 87 countries (870 observations) and data covering $2009-2019$ provided by World Bank. We used two dependent variables: GDP gap and GDP per capita gap, and 12 explanatory variables grouped in 4 categories (the dimension of the state, the quality of public governance, the economic development, and the regional/global economic dependence). The results are robust and significant. They confirm that the dimension of the public intervention and the quality of the public governance and administration have a clear impact on the economic resilience and the ability to recover from business cycles.
\end{abstract}

Keywords: smart city concept, public safety, personal security, video surveillance. 


\section{Introduction}

The concept of economic resilience has become paramount for economic governance. European Union has adopted in 2021 a Recovery and Resilience Plan in order to deal with the impact of COVID-19, while Bloomberg media agency started to calculate a Resilience Index for countries around the world, ranking them according to the perceived quality of responses to the pandemics. From the perspective of economic governance, resilience has indeed become a key objective.

However, a large part of the debates about economic resilience seems not to pay attention to the nature of the economic systems and to the structure of the national economies, especially the weight of the state in the economy. We intend to explore the differences in the performance of the public and private sectors during economic crises and to assess how this is relevant for the dynamics of the entire national economy.

\section{Literature review}

As economic crises have become a permanent reality of the modern global economy, policymakers and scholars alike have increasingly focused on how to deal with such macroeconomics shocks. Several economists (von Mises, 1953, Rothbard, 2000, de Soto, 2009) have long ago explained the origins of economic crises. They argued that economic crises are mainly a result of of monetary policy. By an artificial increase in the money supply and the correspondent expansion of credit, central banks try to capture alleged positive effects such as growth of the economy and increases in investment and employment. Nevertheless, such a monetary policy mechanism comes with a downside. This is the economic recessions that are periods in which the economy and the society return to some natural conditions such as the time preference and the saving ratio of the population. The receipt for avoiding the emergence of the business cycle is clear: discipline the monetary policy and avoid manipulating the money supply and the credit market.

Such a receipt seems to be avoided in contemporary economic governance. The focus of economic theorists and policymakers today has shifted towards another priority, which is called economic resilience. This concept has been defined in various ways. Regibeau and Rockett (2013) noticed, for example, that "a lack of clarity on the concept in the case studies that reflects an enormous spread of definitions used in the literature. This lack of a common vocabulary not only leads to a lack of comparability across the case studies, but also to difficulties implementing resilience policy locally" (p. 107). Meanwhile, Bruneckiene and others (2019) point that "there is a lack of assessment methodology for socio-economic systems' resilience that would, employing either the static or dynamic approach, allow for a comprehensive assessment of the problems of resilience to economic shocks" (p. 565)

Rose (2004) defined economic resilience as "the inherent and adaptive responses to disasters that enable individuals and communities to avoid some potential losses" (p. 307). Such a definition is intuitive and easy to operationalize but is somehow simplistic and static. Duval and Fogel (2008) focus, at their turn, only on one economic indicator, which is the economic output: "economic resilience may be loosely defined as the ability to maintain output close to potential in the aftermath of shocks" (p. 203).

Pendall and others (2010) noticed that there is a difference between defining resilience according to "equilibrium analysis," in which resilience is "the ability to return to a pre-existing state in a single equilibrium system or shift to new "normals" in multiple equilibrium systems." Another definition of the concept is made in terms of complex adaptive systems: from this perspective, economic resilience is "the ability of a system to adapt and change in response to stresses and strains." The same difference is made by Rose (2004, p. 308) when distinguishing between "inherent resilience," that is, "the ability under normal circumstances," and "adaptive resilience," that is, "the ability in crisis situations due to ingenuity or extra effort." Di Pietro, Lecca and Salotti (2020) call it "evolutionary resilience" which is defined as involving "structural and operational adaptation in response to shocks, with economies bouncing forward rather than bouncing back" (p. 3).

The concept of resilience has been explored in other fields of science, such as physics, ecosystems, or spatial geography. For example, disaster management has been one of the most prominent areas of research interested in coherently defining resilience. It focused on infrastructure networks and spatial allocation of economic facilities and activities. The transfer of this concept in the assessment of the performance of economic systems has often been made with an apparent critical error: the ignorance of the nature of the economic systems. This is what Aligica and Tarko (2014) also noticed when stating that they want to focus "on a conceptualization that goes beyond the current emphasis on the socio-ecological facet, that is, only the relationship between natural 
resources and the social system" (p. 54). That is, an attempt to incorporate the perspective of institutions.

In a certain sense, the principles of allocation of economic resources are neutral towards the spatial organization of economic activity. Land is a factor of production, and in consequence, the spatial distribution of natural resources is relevant to the spatial distribution of the economic activities of production and processing. Nevertheless, economics is a lot more than that. Fundamentally, the ownership of the means of production, the freedom of economic activity, the operation of the free market, and the discovery of market prices are even more important than the initial spatial distribution of the economic activity. So the debate about economic resilience is almost irrelevant if it ignores the nature of the economic system. The concept of resilience is not absolute or all-encompassing but relative and derivative. Moreover, Regibeau and Rockett (2013) argue that the measurement of resilience is not so simple and the complexity of society and economy challenges analysts to find the right indicator: „a society may be resilient to one type of shock but not to another... societies may face tradeoffs in resilience policies" (p. 108).

Among the critical differences between the economic system, we could also point to the ratio between the state and the market, namely, the relative importance of the government sector and the private sector. In the government sector, as in a socialist economy, the economic goods are allocated in a centralized manner, by political decision and under the logic of maximization of some politically chosen indicators relevant for the political discourse. Prices are artificial and fixed by political fiat. They do not include any information about economic scarcity (Mises, 1951). Consequently, profit and loss for an undertaking are irrelevant about the utility of the production in the economy. So particular areas or sectors of the economy may perform better under a socialist economic governance because the leadership forces the allocation of resources towards them.

On the other hand, the market system emerges in order to discover the relative scarcity of economic goods. It deals with this scarcity by the exercise of economic freedom. The descentralized system of resource allocation implies a free interplay between supply and demand that leads to the emergence of market prices. Only such prices allow the efficient allocation of scarce economic goods towards potentially infinite needs. As Rose (2004) put it, „the price mechanism is a relatively costless way of redirecting resources and services. Price increases, though often viewed as gouging, serve a useful purpose of reflecting highest value use, even in the broader social setting" (p. 309). Market prices reveal the meaningful profit and loss in economic activity and discipline to erroneous decisions of private individuals and entities. The conclusion of the same author is diamond clear: "what is often less appreciated by disaster researchers outside economics and closely related disciplines is the inherent resilience of markets. Prices act as the invisible hand that can guide resources to their best allocation even in the aftermath of a disaster" (Rose, idem).

So we come close to a critical statement related to the comparative performance of economic systems: markets seem to be nominally more affected by shocks (they react immediately and directly related to the intensity of the shock) than the government sector (it does not take into consideration the dynamics of scarcity). Moreover, decentralized economic systems can be less manipulated in terms of data and statistics as compared to centralized systems. Maximization of specific indicators can be used in order to distort the relative performance of the system. As Pretorius and others argued (2021), "vulnerability is particularly heightened in developing regions due to the relatively smaller size of their economies and the related diversity of economic activities, reduced competitiveness (due to inadequate economies of scale) and limited access to external capital to catalyze productivity" (p. 2674).

Moreover, another dimension that is essential in the study of economic resilience is the level of development of the national economy. As an economy enjoys a significant presence of the market and the allocation of resources relies on market transactions, it experiences a rapid and direct impact from external economic shocks. For the economic sectors that are not directly related to the final demand, the absorption of the impact of economic shocks should take more time, and the economic system appears to be more resilient. It is not, however, a resilience that should be praised as it is a resilience which is a result of isolation from the market and the real interplay between supply and demand. So we suspect that the economic sectors that are closer to the market will be more negatively impacted by external shocks, but they should recover more rapidly than those which are farther away from the ultimate demand.

\section{Methodological approach}

The research aims to explore the determinants of the resilience and recovery of the economies after crisis time by explicitly looking at the indicators referring to the state monetary and fiscal stimulus. The primary research hypothesis derived from this general goal of the research is the 
following: (i) the presence of the state is submitted to help de recovery and to improve de resilience; (ii) the quality of public governance, actions, and policies are influencing the recovery and resilience and (iii) the quality of relationship between the state and the tax payers has an impact on the recovery and resilience. To achieve this specific research hypothesis, we used two main variables to measure the economic growth and economic development: GDP_GAP - real GDP growth rate and GDP_CAP_GAP - GDP per capita (PPP standards). We noticed that, in the case of the "subprime crisis" (one of the most significant and globally contagious crises of the latest decades), the year 2009 could be considered a reference to estimate the recovery and resilience. Therefore, we calculate the gap of these two indicators between the current year and the reference year (2009) for 2010 and 2019. We used three categories of estimating variables to explain them: (a) variables proxying the dimension of the state: CLAIMS_GUV - claims on the central government to GDP, including total loans to the government minus deposits; EXPEND_GOV - government expenditures to GDP for its operating activities in providing public goods and services to the taxpayers and DEFICIT_GOV - public deficit to GDP; (b) variables proxying the quality of the public services: REVEN_GOV - total public revenues to GDP gathered by the government from all taxes applied to economic activities; TIMETAX - time spent to pay the taxes to the government and CONTRIB_RATE - the total taxes to total income rate paid on the net income of the businesses and (c) controlling variables grouped into two subcategories: one category proxying the economic development (RURAL_POP - total population living in the rural area divided to total population, FIXEDCAP - gross fixed capital formation to GDP, MANUF_VA - value added in the manufactured goods to GDP and COM_BALANCE - the net difference between exports and imports to GDP) and other category proxying the correlation with region and global market (CORREL_REG and CORREL_W measured as 10 years rolling correlation between individual real GDP growth rate and GDP per capita and the region / world).

The equations of the model are the following:

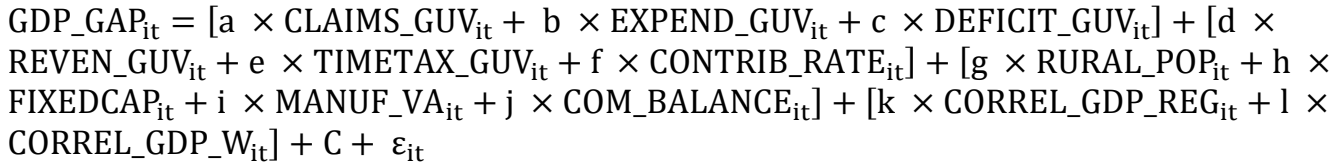

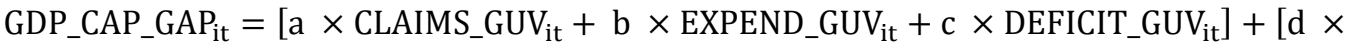
REVEN_GUV $_{i t}+\mathrm{e} \times$ TIMETAX_GUV $_{\text {it }}+\mathrm{f} \times$ CONTRIB_RATE $\left._{i t}\right]+\left[\mathrm{g} \times \mathrm{RURAL}_{-} \mathrm{ROP}_{\mathrm{it}}+\mathrm{h} \times\right.$ FIXEDCAP $_{i t}+\mathrm{i} \times$ MANUF_VA $_{i t}+\mathrm{j} \times$ COM_BALANCE $\left._{\mathrm{it}}\right]+\left[\mathrm{k} \times\right.$ CORREL_GDP_REG $_{i t}+\mathrm{l} \times$ CORREL_GDP_W $\left.\mathrm{W}_{\mathrm{it}}\right]+\mathrm{C}+\varepsilon_{\mathrm{it}}$

The source of data is the Database of the World Bank. The number of countries included in our panel was 87, and the data covers 2009 - 2019 (for GDP_GAP and GDP_CAP_GAP we used ten years rolling correlation, and the data covers 1999 - 2019). In total, the number of country-year observations is 870 . The summary description statistics of the time series are presented in Appendix 1. The panel used for this research is long (significantly more countries than years), balanced (data for all countries), and fixed (data for all years). For the empirical analysis, we used Eviews 12. Because we employed two dependent variables for proxying recovery and resilience (GDP_GAP and GDP_CAP_GAP), we grouped the time series into two different panels. We tested the time series for unit root, and we synthetized the results in Appendix 2. We used the common four unit-root tests for panel data analysis: Levin, Lin and Chu, Im, Pesaran and Shin W-stat, ADF - Fisher Chi-square and PP - Fisher Chi-square. According to the results of these tests, all the time series used in the models are stationary with high significance. We also tested the cointegration in both panel data using Kao Residual Cointegration Test. The results are presented in Appendix 3 and confirm a long-run relationship between the variables included in the model (both panels). Therefore, we performed a more profound analysis based on VECM's error correction term (ECT). We briefly present the results in Appendix 4. The statistically significant negative coefficient for ECT confirmed a long-run solid relationship between both dependent variables (GPD_GAP and GDP_CAP_GAP) and explanatory variables. Additionally, we used the Wald test on the VECM outputs to check the short-run determination for all explanatory variables. The results can be found in Appendix 5 and confirm the short-run relationship with the dependent variable for the following: DEFICIT_GOV, TIMETAX, CONTRIB_RATE, RURAL_POP, MANUF_VA and CORREL_GDP_W (only for the first-panel case).

\section{Results and discussions}

In the first stage of our research, we run the two unrestricted panel regressions according to the specifications of the model. 
Table 1: Unrestricted model outputs

\begin{tabular}{|c|c|c|c|}
\hline Explanatory variable & Outputs & $\begin{array}{c}\text { Panel 1 } \\
-->\text { GDP_GAP }\end{array}$ & $\begin{array}{c}\text { Panel } 2 \\
-->\text { GDPC_GAP }\end{array}$ \\
\hline \multirow{2}{*}{ CLAIMS_GOV } & Coefficient & $-0.0570 *$ & $-0.0647 *$ \\
\hline & p-value & 0.0002 & 0.0000 \\
\hline \multirow{2}{*}{ EXPEND_GOV } & Coefficient & $0.0753^{*}$ & $0.0884^{*}$ \\
\hline & p-value & 0.0002 & 0.0000 \\
\hline \multirow{2}{*}{ DEFICIT_GOV } & Coefficient & -0.0017 & -0.0015 \\
\hline & p-value & 0.9640 & 0.9686 \\
\hline \multirow{2}{*}{ REVEN_GOV } & Coefficient & -0.0483 & $-0.0666^{*}$ \\
\hline & p-value & 0.1553 & 0.0471 \\
\hline \multirow{2}{*}{ TIMETAX } & Coefficient & $-0.0030 *$ & -0.0017 \\
\hline & p-value & 0.0269 & 0.2057 \\
\hline \multirow{2}{*}{ CONTRIB_RATE } & Coefficient & -0.0124 & -0.0100 \\
\hline & p-value & 0.6125 & 0.2578 \\
\hline \multirow{2}{*}{ RURAL_POP } & Coefficient & 0.0041 & $0.0164^{*}$ \\
\hline & p-value & 0.7760 & 0.0428 \\
\hline \multirow{2}{*}{ FIXEDCAP } & Coefficient & $-0.0053^{*}$ & -0.0074 \\
\hline & p-value & 0.0246 & 0.6896 \\
\hline \multirow{2}{*}{ MANUF_VA } & Coefficient & $0.0580^{*}$ & $0.0525^{*}$ \\
\hline & p-value & 0.0246 & 0.0386 \\
\hline \multirow{2}{*}{ COM_BALANCE } & Coefficient & $-0.0293^{*}$ & -0.0174 \\
\hline & p-value & 0.0164 & 0.1504 \\
\hline \multirow{2}{*}{ CORREL_GDP_REG } & Coefficient & $-0.9937^{* * *}$ & $-1.0071^{* * *}$ \\
\hline & p-value & 0.1178 & 0.1076 \\
\hline \multirow{2}{*}{ CORREL_GDP_W } & Coefficient & $9.8979^{*}$ & $10.3068^{*}$ \\
\hline & p-value & 0.0000 & 0.0000 \\
\hline \multirow[b]{2}{*}{$\mathrm{C}$} & Coefficient & -0.9782 & $-1.7951^{* * *}$ \\
\hline & p-value & 0.3459 & 0.0816 \\
\hline Adjusted R-Squared & & 0.5181 & 0.5247 \\
\hline F-Statistic & & 76.7757 & 80.9291 \\
\hline
\end{tabular}

Source: own estimations based on data from World Bank ${ }^{*}-1 \%$ significance, ${ }^{* *}$ - 5\% significance, ${ }^{* * *}$ - $10 \%$ significance

The results summarized in the Table 1 for both unrestricted models indicate a negative and significant influence on the GDP_GAP of the following explanatory variables only: CLAIMS_GOV, CONTRIB_RATE, FIXEDCAP, COM_BALANCE and COREL_GDP_REG. The positive and significant impact is observed only for EXPEND_GOV. For the other dependent variable - GDP_CAP_GAP, we observed a negative and significant influence in the case of CLAIMS_GOV, REVEN_GOV, CORREL_GDP_W and intercept. The positive and significant influence is observed only for EXPEND_GOV, RURAL_POP and MANUF_VA.

Table 2: Restricted model - Panel 1 (GDP_GAP dependent variable)

\begin{tabular}{|c|c|c|c|c|c|c|c|c|c|}
\hline \multirow{3}{*}{$\begin{array}{l}\text { Explanatory variable: } \\
\text { CLAIMS_GOV }\end{array}$} & \multicolumn{9}{|c|}{$\begin{array}{c}\text { Restricted models - Panel } 1 \text { (dependent variable GDP_GAP) } \\
-->\text { GDP_GAP }\end{array}$} \\
\hline & -0.052 & & & -0.056 & & & -0.052 & & \\
\hline & 0.000 & & & 0.000 & & & 0.000 & & \\
\hline \multirow{2}{*}{ EXPEND_GOV } & & 0.061 & & & 0.056 & & & 0.058 & \\
\hline & & 0.002 & & & 0.000 & & & 0.000 & \\
\hline \multirow{2}{*}{ DEFICIT_GOV } & & & 0.025 & & & 0.033 & & & 0.030 \\
\hline & & & 0.469 & & & 0.341 & & & 0.386 \\
\hline \multirow{2}{*}{ REVEN_GOV } & 0.054 & -0.004 & 0.063 & & & & & & \\
\hline & 0.025 & 0.892 & 0.009 & & & & & & \\
\hline \multirow{2}{*}{ TIMETAX } & & & & -0.004 & -0.002 & -0.003 & & & \\
\hline & & & & 0.004 & 0.084 & 0.025 & & & \\
\hline \multirow{2}{*}{ CONTRIB_RATE } & & & & & & & -0.015 & -0.017 & -0.019 \\
\hline & & & & & & & 0.077 & 0.047 & 0.031 \\
\hline \multirow{2}{*}{ RURAL_POP } & -0.001 & 0.016 & 0.011 & -0.003 & 0.018 & 0.009 & -0.006 & 0.015 & 0.006 \\
\hline & 0.861 & 0.041 & 0.169 & 0.678 & 0.029 & 0.264 & 0.465 & 0.055 & 0.460 \\
\hline \multirow{2}{*}{ FIXEDCAP } & -0.011 & 0.027 & 0.015 & -0.022 & 0.025 & 0.006 & -0.017 & 0.027 & 0.008 \\
\hline & 0.540 & 0.142 & 0.410 & 0.233 & 0.178 & 0.754 & 0.347 & 0.141 & 0.656 \\
\hline \multirow{2}{*}{ MANUF_VA } & 0.050 & 0.031 & 0.037 & 0.049 & 0.040 & 0.029 & 0.039 & 0.039 & 0.025 \\
\hline & 0.053 & 0.228 & 0.156 & 0.052 & 0.112 & 0.256 & 0.116 & 0.118 & 0.317 \\
\hline \multirow{2}{*}{ COM_BALANCE } & -0.025 & -0.003 & -0.006 & -0.035 & -0.006 & -0.016 & -0.028 & -0.001 & -0.011 \\
\hline & 0.035 & 0.773 & 0.592 & 0.002 & 0.614 & 0.168 & 0.015 & 0.928 & 0.368 \\
\hline \multirow{2}{*}{ CORREL_GDP_REG } & -0.433 & -1.155 & -0.617 & -0.319 & -1.047 & -0.540 & -0.471 & -1.157 & -0.661 \\
\hline & 0.483 & 0.074 & 0.326 & 0.606 & 0.100 & 0.392 & 0.446 & 0.068 & 0.293 \\
\hline \multirow{2}{*}{ CORREL_GDP_W } & 10.090 & 10.641 & 10.489 & 9.926 & 10.382 & 10.502 & 10.257 & 10.491 & 10.681 \\
\hline & 0.000 & 0.000 & 0.000 & 0.000 & 0.000 & 0.000 & 0.000 & 0.000 & 0.000 \\
\hline \multirow{2}{*}{$\mathrm{C}$} & -1.882 & -4.075 & -3.408 & 0.271 & -3.558 & -1.276 & 0.039 & -3.373 & -1.102 \\
\hline & 0.033 & 0.000 & 0.000 & 0.703 & 0.000 & 0.063 & 0.958 & 0.000 & 0.128 \\
\hline Adjusted R-Sq. & 0.500 & 0.486 & 0.481 & 0.502 & 0.488 & 0.480 & 0.499 & 0.489 & 0.479 \\
\hline F-Statistic & 109.74 & 103.86 & 101.54 & 110.59 & 104.59 & 101.1 & 109.25 & 104.83 & 101.03 \\
\hline
\end{tabular}

Source: own estimations based on data from World Bank 
In the next step of the analysis, we restricted the models by grouping the explanatory variables into considered groups, the controlling variables being kept the same for all models. The restricted models for Panel 1 are presented in Table 2 and for Panel 2 in Table 3. In the case of Panel 1 (dependent variable is GDP gap), the outputs confirmed a negative and statistically significant influence on GDP gap is registered for: CLAIMS_GOV, COM_BALANCE, and intercept. We confirm a positive and statistically significant influence on the GDP gap for: REVEN_GOV, MANUF_VA, and CORREL_GDP_W. For Panel 2 (dependent variable is GDP per capita gap), a negative and statistically significant influence on GDP per capita gap is confirmed for: CLAIMS_GOV, CONTRIB_RATE and intercept. A positive and statistically significant influence on GDP per capita gap is confirmed for: EXPEND_GOV, REVEN_GOV, RURAL_POP and CORREL_GDPC_W. Moreover, F-statistic confirmed a robust statistical significance for all restricted models, both panels and Adjusted R squared that indicates a medium intensity for the correlation between both dependent and all explanatory variables included in the restricted models.

\begin{tabular}{|c|c|c|c|c|c|c|c|c|c|}
\hline \multirow{3}{*}{$\begin{array}{l}\text { Explanatory variable: } \\
\text { CLAIMS_GOV }\end{array}$} & \multicolumn{9}{|c|}{$\begin{array}{l}\text { Restricted models - Panel } 2 \text { (dependent variable GDP_CAP_GAP) } \\
\text {--> GDP per capita_GAP }\end{array}$} \\
\hline & -0.060 & & & -0.063 & & & -0.060 & & \\
\hline & 0.000 & & & 0.000 & & & 0.000 & & \\
\hline \multirow{2}{*}{ EXPEND_GOV } & & 0.072 & & & 0.062 & & & 0.062 & \\
\hline & & 0.000 & & & 0.000 & & & 0.000 & \\
\hline \multirow{2}{*}{ DEFICIT_GOV } & & & 0.030 & & & 0.036 & & & 0.035 \\
\hline & & & 0.382 & & & 0.307 & & & 0.321 \\
\hline \multirow{2}{*}{ REVEN_GOV } & 0.044 & -0.025 & 0.055 & & & & & & \\
\hline & 0.062 & 0.433 & 0.023 & & & & & & \\
\hline \multirow{2}{*}{ TIMETAX } & & & & -0.002 & -0.001 & -0.002 & & & \\
\hline & & & & 0.059 & 0.580 & 0.252 & & & \\
\hline \multirow{2}{*}{ CONTRIB_RATE } & & & & & & & -0.010 & -0.012 & -0.014 \\
\hline & & & & & & & 0.255 & 0.161 & 0.112 \\
\hline \multirow{2}{*}{ RURAL_POP } & 0.010 & 0.031 & 0.025 & 0.008 & 0.032 & 0.022 & 0.007 & 0.030 & 0.020 \\
\hline & 0.208 & 0.000 & 0.002 & 0.291 & 0.000 & 0.005 & 0.391 & 0.000 & 0.009 \\
\hline \multirow{2}{*}{ FIXEDCAP } & -0.017 & 0.028 & 0.014 & -0.025 & 0.027 & 0.006 & -0.022 & 0.028 & 0.007 \\
\hline & 0.346 & 0.126 & 0.463 & 0.165 & 0.139 & 0.738 & 0.222 & 0.128 & 0.684 \\
\hline \multirow{2}{*}{ MANUF_VA } & 0.051 & 0.028 & 0.036 & 0.047 & 0.036 & 0.024 & 0.040 & 0.039 & 0.024 \\
\hline & 0.045 & 0.270 & 0.165 & 0.059 & 0.150 & 0.339 & 0.097 & 0.121 & 0.332 \\
\hline \multirow{2}{*}{ COM_BALANCE } & -0.015 & 0.010 & 0.007 & -0.023 & 0.011 & -0.001 & -0.018 & 0.013 & 0.003 \\
\hline & 0.210 & 0.352 & 0.584 & 0.050 & 0.336 & 0.941 & 0.120 & 0.240 & 0.826 \\
\hline \multirow{2}{*}{ CORREL_GDPC_REG } & -0.321 & -1.134 & -0.483 & -0.195 & -1.010 & -0.401 & -0.316 & -1.052 & -0.477 \\
\hline & 0.596 & 0.076 & 0.437 & 0.749 & 0.111 & 0.522 & 0.602 & 0.095 & 0.443 \\
\hline \multirow{2}{*}{ CORREL_GDPC_W } & 10.334 & 10.972 & 10.762 & 10.236 & 10.780 & 10.864 & 10.475 & 10.759 & 10.927 \\
\hline & 0.000 & 0.000 & 0.000 & 0.000 & 0.000 & 0.000 & 0.000 & 0.000 & 0.000 \\
\hline \multirow{2}{*}{$\mathrm{C}$} & -2.072 & -4.675 & -3.854 & -0.450 & -4.725 & -2.226 & -0.613 & -4.379 & -1.964 \\
\hline & 0.018 & 0.000 & 0.000 & 0.530 & 0.000 & 0.001 & 0.406 & 0.000 & 0.007 \\
\hline Adjusted R-Squared & 0.513 & 0.495 & 0.487 & 0.513 & 0.495 & 0.485 & 0.512 & 0.496 & 0.485 \\
\hline F-Statistic & 115.36 & 107.50 & 104.11 & 115.38 & 107.43 & 103.16 & 114.79 & 107.84 & 103.46 \\
\hline
\end{tabular}

Source: own estimations based on data from World Bank

To avoid possible biases in the outputs, the consequently step recommended in the panel data analysis is to test the estimators for the fixed effects (omitted factors that are constant over time but are changing over the countries) and the random effects (omitted factors that are constant over countries but are changing overtime). We used the Hausman Random Effects test for testing crosssection and period random effects and the Redundant Fixed Effects test for cross-section and period fixed effects. The results of the Hausman tests and the Redundant Fixed Effects tests for all restricted models for Panel 1 (dependent variable is GDP gap) are summarized in Table 4 and for Panel 2 (dependent variable is GDP per capita gap) are summarized in Table 5 (Chi-statistic values and pvalues).

According to the results of these tests, we noticed that the cross-section random effects are present in all restricted models, both panels, but period random effects are not present. The fixed effects are present for all restricted models, both panels, cross-section, and period too. Therefore, these results recommend using cross-section random effects and period fixed effects to fit the estimators of the models.

In the final step of our analysis, we estimated again the outputs of the restricted models for both panels by introducing the conditions of cross-section random effects and period fixed effects in the regressions (a method used is Panel EGLS). We summarized the final fitted estimators for Panel 1 (dependent variable GDP gap) in Table 6 and for Panel 2 (dependent variable GDP per capita gap) in Table 7. As a general remark, the statistical significance was improved for all coefficients, all 
restricted models, both panels by introducing the cross-section random effects and period fixed effects restrictions.

\begin{tabular}{|c|c|c|c|c|c|c|c|c|}
\hline \multirow{3}{*}{$\begin{array}{l}\text { Panel 1: ---> GDP } \\
\text { Growth GAP }\end{array}$} & \multicolumn{4}{|c|}{ Redundant Fixed Effects Test } & \multicolumn{4}{|c|}{ Hausman Random Effects Test } \\
\hline & \multicolumn{2}{|c|}{$\begin{array}{c}\text { Cross section fixed } \\
\text { effects }\end{array}$} & \multicolumn{2}{|c|}{ Period fixed effects } & \multicolumn{2}{|c|}{$\begin{array}{l}\text { Cross section } \\
\text { random effects }\end{array}$} & \multicolumn{2}{|c|}{$\begin{array}{c}\text { Period random } \\
\text { effects }\end{array}$} \\
\hline & Chi-stat. & Prob. & Chi-stat. & Prob. & Chi-stat. & Prob. & Chi-stat. & Prob. \\
\hline Restricted model 1 & 2162.459 & 0.000 & 38.327 & 0.000 & 121.051 & 0.000 & 10.192 & 0.252 \\
\hline Restricted model 2 & 2265.361 & 0.000 & 63.013 & 0.000 & 176.829 & 0.000 & 10.586 & 0.226 \\
\hline Restricted model 3 & 2274.841 & 0.000 & 58.562 & 0.000 & 149.970 & 0.000 & 11.049 & 0.199 \\
\hline Restricted model 4 & 2176.916 & 0.000 & 24.150 & 0.004 & 134.344 & 0.000 & 10.437 & 0.236 \\
\hline Restricted model 5 & 2278.090 & 0.000 & 34.779 & 0.000 & 192.101 & 0.000 & 10.881 & 0.209 \\
\hline Restricted model 6 & 2307.2369 & 0.000 & 41.019 & 0.000 & 155.487 & 0.000 & 11.322 & 0.184 \\
\hline Restricted model 7 & 2179.492 & 0.000 & 26.788 & 0.002 & 130.660 & 0.000 & 10.470 & 0.234 \\
\hline Restricted model 8 & 2264.214 & 0.000 & 39.767 & 0.000 & 189.135 & 0.000 & 10.911 & 0.207 \\
\hline Restricted model 9 & 2293.083 & 0.000 & 46.621 & 0.000 & 155.137 & 0.000 & 11.150 & 0.193 \\
\hline
\end{tabular}

Source: own estimations based on data from World Bank

\begin{tabular}{|c|c|c|c|c|c|c|c|c|}
\hline \multirow{3}{*}{$\begin{array}{l}\text { Panel 2: ---> GDP } \\
\text { per capita growth } \\
\text { GAP }\end{array}$} & \multicolumn{4}{|c|}{ Redundant Fixed Effects Test } & \multicolumn{4}{|c|}{ Hausman Random Effects Test } \\
\hline & \multicolumn{2}{|c|}{$\begin{array}{c}\text { Cross-section fixed } \\
\text { effects }\end{array}$} & \multicolumn{2}{|c|}{ Period fixed effects } & \multicolumn{2}{|c|}{$\begin{array}{l}\text { Cross-section } \\
\text { random effects }\end{array}$} & \multicolumn{2}{|c|}{$\begin{array}{c}\begin{array}{c}\text { Period random } \\
\text { effects }\end{array} \\
\end{array}$} \\
\hline & Chi-stat. & Prob. & Chi-stat. & Prob. & Chi-stat. & Prob. & Chi-stat. & Prob. \\
\hline Restricted model 1 & 2175.306 & 0.000 & 37.981 & 0.000 & 110.938 & 0.000 & 10.036 & 0.263 \\
\hline Restricted model 2 & 2273.074 & 0.000 & 61.878 & 0.000 & 167.536 & 0.000 & 10.361 & 0.241 \\
\hline Restricted model 3 & 2287.030 & 0.000 & 57.602 & 0.000 & 140.421 & 0.000 & 10.884 & 0.208 \\
\hline Restricted model 4 & 2190.048 & 0.000 & 23.635 & 0.005 & 123.336 & 0.000 & 10.104 & 0.258 \\
\hline Restricted model 5 & 2285.155 & 0.000 & 33.025 & 0.000 & 180.835 & 0.000 & 10.487 & 0.233 \\
\hline Restricted model 6 & 2321.7871 & 0.000 & 39.261 & 0.000 & 146.825 & 0.000 & 10.916 & 0.207 \\
\hline Restricted model 7 & 2185.429 & 0.000 & 26.918 & 0.001 & 120.055 & 0.000 & 10.148 & 0.255 \\
\hline Restricted model 8 & 2264.863 & 0.000 & 39.084 & 0.000 & 176.925 & 0.000 & 10.626 & 0.224 \\
\hline Restricted model 9 & 2300.885 & 0.000 & 46.258 & 0.000 & 146.116 & 0.000 & 10.967 & 0.204 \\
\hline
\end{tabular}

Source: own estimations based on data from World Bank

\begin{tabular}{|c|c|c|c|c|c|c|c|c|c|}
\hline \multirow{3}{*}{$\begin{array}{l}\begin{array}{l}\text { Explanatory } \\
\text { variable: }\end{array} \\
\text { CLAIMS_GOV }\end{array}$} & \multicolumn{9}{|c|}{$\begin{array}{c}\text { Fitted Estimators - Restricted models - Panel } 1 \\
\text {--> GDP_GAP }\end{array}$} \\
\hline & -0.030 & & & -0.036 & & & -0.032 & & \\
\hline & 0.025 & & & 0.000 & & & 0.000 & & \\
\hline \multirow{2}{*}{ EXPEND_GOV } & & -0.119 & & & -0.097 & & & -0.094 & \\
\hline & & 0.000 & & & 0.000 & & & 0.000 & \\
\hline \multirow{2}{*}{ DEFICIT_GOV } & & & 0.126 & & & 0.113 & & & 0.129 \\
\hline & & & 0.000 & & & 0.000 & & & 0.000 \\
\hline \multirow{2}{*}{ REVEN_GOV } & 0.086 & 0.143 & 0.041 & & & & & & \\
\hline & 0.008 & 0.000 & 0.106 & & & & & & \\
\hline \multirow{2}{*}{ TIMETAX } & & & & 0.005 & 0.005 & 0.007 & & & \\
\hline & & & & 0.000 & 0.000 & 0.000 & & & \\
\hline \multirow{2}{*}{$\begin{array}{l}\text { CONTRIB_RA } \\
\text { TE }\end{array}$} & & & & & & & 0.019 & 0.020 & 0.016 \\
\hline & & & & & & & 0.001 & 0.000 & 0.003 \\
\hline \multirow{2}{*}{ RURAL_POP } & -0.020 & -0.037 & -0.024 & -0.004 & -0.046 & -0.024 & -0.023 & -0.038 & -0.024 \\
\hline & 0.096 & 0.045 & 0.191 & 0.984 & 0.013 & 0.191 & 0.204 & 0.041 & 0.185 \\
\hline \multirow{2}{*}{ FIXEDCAP } & 0.061 & 0.045 & 0.066 & 0.055 & 0.055 & 0.066 & 0.068 & 0.060 & 0.070 \\
\hline & 0.034 & 0.000 & 0.000 & 0.000 & 0.000 & 0.000 & 0.000 & 0.000 & 0.000 \\
\hline \multirow{2}{*}{ MANUF_VA } & 0.071 & 0.032 & 0.036 & 0.057 & -0.005 & 0.036 & 0.053 & 0.009 & 0.028 \\
\hline & 0.018 & 0.253 & 0.191 & 0.040 & 0.863 & 0.191 & 0.055 & 0.742 & 0.295 \\
\hline \multirow{2}{*}{$\begin{array}{l}\text { COM_BALAN } \\
\text { CE }\end{array}$} & 0.032 & 0.019 & 0.010 & 0.029 & 0.020 & 0.010 & 0.029 & 0.019 & 0.008 \\
\hline & 0.130 & 0.056 & 0.334 & 0.003 & 0.038 & 0.334 & 0.003 & 0.053 & 0.410 \\
\hline \multirow{2}{*}{$\begin{array}{l}\text { CORREL_GDP } \\
\text { REG }\end{array}$} & -0.675 & -0.653 & -0.523 & -0.759 & -0.706 & -0.523 & -0.821 & -0.821 & -0.649 \\
\hline & 0.300 & 0.040 & 0.101 & 0.022 & 0.025 & 0.101 & 0.014 & 0.011 & 0.042 \\
\hline \multirow{2}{*}{$\begin{array}{l}\text { CORREL_GDP } \\
\text { _W }\end{array}$} & 1.384 & 1.459 & 1.273 & 1.524 & 1.418 & 1.273 & 1.574 & 1.637 & 1.409 \\
\hline & 0.105 & 0.001 & 0.003 & 0.000 & 0.001 & 0.003 & 0.000 & 0.000 & 0.001 \\
\hline \multirow{2}{*}{ C } & 1.369 & 4.813 & 2.574 & 1.467 & 6.540 & 2.574 & 2.358 & 5.907 & 2.666 \\
\hline & 0.135 & 0.000 & 0.010 & 0.089 & 0.000 & 0.010 & 0.007 & 0.000 & 0.002 \\
\hline \multicolumn{10}{|l|}{ Adjusted R- } \\
\hline Squared & 0.144 & 0.176 & 0.197 & 0.108 & 0.163 & 0.197 & 0.144 & 0.160 & 0.203 \\
\hline F-Statistic & 9.611 & 11.946 & 13.571 & 14.199 & 10.991 & 13.571 & 9.582 & 10.745 & 14.024 \\
\hline $\begin{array}{l}\text { Random } \\
\text { Effects }\end{array}$ & $\begin{array}{l}\text { Cross- } \\
\text { section }\end{array}$ & $\begin{array}{l}\text { Cross- } \\
\text { section }\end{array}$ & $\begin{array}{l}\text { Cross- } \\
\text { section }\end{array}$ & $\begin{array}{l}\text { Cross- } \\
\text { section }\end{array}$ & $\begin{array}{l}\text { Cross- } \\
\text { section }\end{array}$ & $\begin{array}{l}\text { Cross- } \\
\text { section }\end{array}$ & $\begin{array}{l}\text { Cross- } \\
\text { section }\end{array}$ & $\begin{array}{l}\text { Cross- } \\
\text { section }\end{array}$ & $\begin{array}{l}\text { Cross- } \\
\text { section }\end{array}$ \\
\hline Fixed Effects & Period & Period & Period & Period & Period & Period & Period & Period & Period \\
\hline
\end{tabular}

Source: own estimations based on data from World Bank 
For Panel 1 (GDP gap as dependent variable) we obtained a negative and statistically relevant influence on the GDP gap for the following explanatory variables: CLAIMS_GOV, EXPEND_GOV, RURAL_POP, and CORREL_GDP_REG. A positive and statistically relevant influence on the GDP gap was obtained for the following variables: DEFICIT_GOV, REVENUE_GOV, TIMETAX, CONTRIB_RATE, FIXEDCAP, COM_BALANCE, CORREL_GDP_W, and intercept. We did not notice statistical relevance for MANUF_VA (positive impact). F-statistic values confirmed that all restricted models are statistically significant.

The fitted estimators with cross-section random effects and period fixed effects summarized in Table 7 confirmed a negative and statistical relevant influence on the GDP per capita gap for the following explanatory variables: CLAIMS_GOV, EXPEND_GOV, RURAL_POP, and CORREL_GDPC_REG and $a$ positive and statistical relevant influence on the GDP per capita gap for the following explanatory variables: DEFICIT_GOV, REVEN_GOV, FIXEDCAP, MANUF_VA, COM_BALANCE, CORREL_GDPC_W, and intercept. In this case, all explanatory variables are highly statistically significant. F-statistic indicates a statistically significance for all fitted restricted models.

Moreover, we can observe that the results are similar between the considered two panels (GDP gap and GDP per capita gap), the same negative and positive influences being finally indicated by both of them, with no exceptions. This confirms the robustness of our findings too.

\begin{tabular}{|c|c|c|c|c|c|c|c|c|c|}
\hline \multirow{3}{*}{$\begin{array}{l}\begin{array}{l}\text { Explanatory } \\
\text { variable: }\end{array} \\
\text { CLAIMS_GOV }\end{array}$} & \multicolumn{9}{|c|}{$\begin{array}{c}\text { Fitted Estimators - Restricted models - Panel } 2 \\
-->\text { GDP_CAP_GAP }\end{array}$} \\
\hline & -0.037 & & & -0.036 & & & -0.039 & & \\
\hline & 0.000 & & & 0.000 & & & 0.000 & & \\
\hline \multirow{2}{*}{ EXPEND_GOV } & & -0.110 & & & -0.088 & & & -0.085 & \\
\hline & & 0.000 & & & 0.000 & & & 0.000 & \\
\hline \multirow{2}{*}{ DEFICIT_GOV } & & & 0.100 & & & 0.109 & & & 0.124 \\
\hline & & & 0.000 & & & 0.000 & & & 0.000 \\
\hline \multirow{2}{*}{ REVEN_GOV } & 0.092 & 0.148 & 0.022 & & & & & & \\
\hline & 0.000 & 0.000 & 0.375 & & & & & & \\
\hline \multirow{2}{*}{ TIMETAX } & & & & 0.003 & 0.003 & 0.006 & & & \\
\hline & & & & 0.003 & 0.000 & 0.000 & & & \\
\hline \multirow{2}{*}{$\begin{array}{l}\text { CONTRIB_RA } \\
\text { TE }\end{array}$} & & & & & & & 0.015 & 0.016 & 0.013 \\
\hline & & & & & & & 0.007 & 0.003 & 0.017 \\
\hline \multirow{2}{*}{ RURAL_POP } & -0.017 & -0.032 & 0.037 & -0.026 & -0.041 & 0.037 & -0.021 & -0.034 & -0.022 \\
\hline & 0.352 & 0.081 & 0.029 & 0.142 & 0.026 & 0.029 & 0.238 & 0.070 & 0.229 \\
\hline \multirow{2}{*}{ FIXEDCAP } & 0.046 & 0.033 & 0.046 & 0.050 & 0.043 & 0.046 & 0.053 & 0.049 & 0.057 \\
\hline & 0.000 & 0.006 & 0.000 & 0.000 & 0.000 & 0.000 & 0.000 & 0.000 & 0.000 \\
\hline \multirow{2}{*}{ MANUF_VA } & 0.101 & 0.063 & 0.087 & 0.071 & 0.026 & 0.087 & 0.081 & 0.040 & 0.055 \\
\hline & 0.000 & 0.023 & 0.002 & 0.009 & 0.342 & 0.002 & 0.003 & 0.148 & 0.040 \\
\hline \multirow{2}{*}{$\begin{array}{l}\text { COM_BALAN } \\
\text { CE }\end{array}$} & 0.026 & 0.014 & 0.004 & 0.024 & 0.016 & 0.004 & 0.023 & 0.015 & 0.003 \\
\hline & 0.008 & 0.133 & 0.671 & 0.011 & 0.099 & 0.671 & 0.018 & 0.131 & 0.743 \\
\hline CORREL_GDP & -0.874 & -0.919 & -0.855 & -0.919 & -0.994 & -0.855 & -1.002 & -1.089 & -0.911 \\
\hline \multirow{2}{*}{$\begin{array}{l}\text { REG } \\
\text { CORREL_GDP }\end{array}$} & 0.007 & 0.003 & 0.007 & 0.004 & 0.001 & 0.007 & 0.002 & 0.001 & 0.003 \\
\hline & 1.949 & 1.925 & 2.133 & 1.959 & 1.914 & 2.133 & 2.115 & 2.108 & 1.849 \\
\hline \multirow[t]{2}{*}{ _W } & 0.000 & 0.000 & 0.000 & 0.000 & 0.000 & 0.000 & 0.000 & 0.000 & 0.000 \\
\hline & 0.990 & 4.098 & 0.152 & 2.641 & 5.895 & 0.152 & 2.288 & 5.420 & 2.593 \\
\hline $\mathrm{C}$ & 0.319 & 0.000 & 0.883 & 0.002 & 0.000 & 0.883 & 0.008 & 0.000 & 0.003 \\
\hline \multicolumn{10}{|l|}{ Adjusted R- } \\
\hline Squared & 0.154 & 0.174 & 0.113 & 0.150 & 0.159 & 0.113 & 0.149 & 0.152 & 0.196 \\
\hline F-Statistic & 10.322 & 11.767 & 14.888 & 10.005 & 10.654 & 14.888 & 9.926 & 10.140 & 13.47 \\
\hline $\begin{array}{l}\text { Random } \\
\text { Effects }\end{array}$ & $\begin{array}{l}\text { Cross- } \\
\text { section }\end{array}$ & $\begin{array}{l}\text { Cross- } \\
\text { section }\end{array}$ & $\begin{array}{l}\text { Cross- } \\
\text { section }\end{array}$ & $\begin{array}{l}\text { Cross- } \\
\text { section }\end{array}$ & $\begin{array}{l}\text { Cross- } \\
\text { section }\end{array}$ & $\begin{array}{l}\text { Cross- } \\
\text { section }\end{array}$ & $\begin{array}{l}\text { Cross- } \\
\text { section }\end{array}$ & $\begin{array}{l}\text { Cross- } \\
\text { section }\end{array}$ & $\begin{array}{l}\text { Cross- } \\
\text { section }\end{array}$ \\
\hline Fixed Effects & Period & Period & Period & Period & Period & Period & Period & Period & Period \\
\hline
\end{tabular}

Source: own estimations based on data from World Bank

Based on these results, we can conclude that the economic resilience and recovery, proxied by GDP gap and GDP per capita gap, are consistent positively influenced by lower claims of the government, lower public expenditures, lower rural population (higher development rate), lower correlation with the region (neighboring countries, generally having similar problems), higher fiscal revenues for the government, higher investments in the economy, higher commercial balance, higher value added by the manufacturing sector and higher correlation with the global markets. These findings are consistent with the theoretical background too.

A separate discussion could be started in the case of the following identified influences on the GDP gap and GDP per capita gap: the time spent to pay taxes that seems to increase the economic resilience and recovery and the contribution rate that is positively influencing the economic resilience and recovery. Further research may explore a deeper additional investigation in the case of public deficit that seems to help de economic recovery and resilience. We consider these findings 
as inconsistent with the economic theory and practice. They require a deeper investigation in further studies.

\section{Conclusion}

This research discusses a key issue in the economic theory and practice derived from the business cycle topic: economic resilience and recovery. In modern economies, the volatility of business cycles significantly increased, doubled by a significant time reduction between two consecutive cycles (boom and bust). In this context, the way in which a country can correct the negative impact of economic recessions becomes very important. The public policies addressed to structural macroeconomic problems should take into consideration the unique context of each country and should avoid being pro-cyclical. The way in which we analyze and measure the economic resilience and recovery, the factors we are taking as relevant for this issue and the solutions that could improve the response to these structural problems are highly debated now.

Our study used real GDP growth rate and GDP per capita growth rate to estimate economic growth and development. 2009 was considered reference year for after crisis economic recovery. We calculated the GDP gap and GDP per capita GAP for the period of 2010 - 2019 in reference to that particular year. These 2009 gaps for GDP and GDP per capita are used as proxies for economic recovery and resilience. The empirical research applied on a panel of 87 countries covering ten years confirmed that the economic recovery and resilience after crisis is influenced by lower public debt, lower public expenditures, higher investments, higher value-added by the private sector, lower external trade deficits, higher integration in the global economy and lower integration in the region. The findings are inconsistent in the case of time spent to pay taxes, contribution rate, and public deficit, requiring a closer and deeper investigation in further studies on the subject. The findings are consistent, robust, and statistically significant.

Our study is relevant for the problem of economic recovery and resilience after the crisis, providing a helpful insight on the possible determinants of the capacity of a nation to properly manage the consequences of recessions. The study offers a consistent perspective on the role of the public sector and public policies to improve the resilience capacity. Understanding of these explanatory factors studied by our research is useful for anti-cyclical public policies that can boost the recovery after each crisis. Any public policy that boosts the investments, tempers the public debt, boosts the exports, opens the economy, keeps under control the public expenditures and stimulates the increase of value added by introducing new stages of production makes countries to be more resilient.

This study is limited by using GDP and GDP per capita as proxies for economic growth and development. The limitations of GDP in this respect are already recognized in the economic literature. Some indicators such as public deficit, time spent to pay taxes and contribution rate require a deeper investigation because of their theoretical inconsistences. Further developments of our research will consider all these limitations and inconsistences.

\section{Funding}

The author(s) received no financial support for the research, authorship, and/or publication of this article.

\section{Declaration of conflicting interests}

The author(s) declared no potential conflicts of interest with respect to the research, authorship, and/or publication of this article.

\section{Citation information}

Paun, C.-V., Musetescu, R.-C., Isaic, R., Manea G. C., \& Shayb H.-A. (2021). Economic resilience and the state: A global panel analysis. Economics, Management and Sustainability, 6(2), 34-45. doi:10.14254/jems.2021.6-2.3 


\section{Reference}

Acemoglu, D., Johnson, S., Robinson. I., \& Thaicharoen, Y. (2004). Institutional causes. Macroeconomic simptoms: Volatility, crises and growth. Journal of Monetary Economics, 50(1), 49-123.

Aligica, P. D., \& Tarko, V. (2014). Institutional resilience and economic systems: lessons from Elinor Ostrom's work. Comparative Economic Studies, 56(1), 52-76.

Bruneckiene, J., Pekarskiene, I., Palekiene, O., \& Simanaviciene, Z. (2019). An assessment of socioeconomic systems' resilience to economic shocks: The case of Lithuanian regions. Sustainability, 11(3), 566-589.

De Soto, J. H. (2006). Money, bank credit, and economic cycles. Ludwig von Mises Institute.

Di Pietro, F., Lecca, P., \& Salotti, S. (2021). Regional economic resilience in the European Union: a numerical general equilibrium analysis. Spatial Economic Analysis, 16(3), 287-312.

Duval, R., \& Vogel, L. (2008). Economic resilience to shocks: The role of structural policies. OECD Journal: Economic Studies, 2008(1), 1-38.

Pendall, R., Foster, K. A., \& Cowell, M. (2010). Resilience and regions: building understanding of the metaphor. Cambridge Journal of Regions, Economy and Society, 3(1), 71-84.

Pretorius, O., Drewes, E., van Aswegen, M., \& Malan, G. (2021). A Policy Approach towards Achieving Regional Economic Resilience in Developing Countries: Evidence from the SADC. Sustainability, 13(5), 2674-2695.

Régibeau, P., \& Rockett, K. (2013). Economic analysis of resilience: A framework for local policy response based on new case studies. Journal of Innovation Economics Management, (1), 107147.

Rose, A. (2004). Defining and measuring economic resilience to disasters. Disaster Prevention and Management: An International Journal, 13(4), 307-314.

Rothbard, M. N. (2000). America's Great Depression (Auburn. Ala: Ludwig von Mises Institute.

von Mises, L. (1951). Socialism: An Economic and Sociological Analysis (p. 600). Macmillan Company.

von Mises, L. (1953). The theory of money and credit (p. 462). New Haven: Yale University Press. 


\begin{tabular}{|c|c|c|c|c|c|c|c|c|}
\hline & GDP_GAP & $\begin{array}{c}\text { GDP_CAP_ } \\
\text { GAP }\end{array}$ & $\begin{array}{c}\text { CLAIMS } \\
\text { GOV }\end{array}$ & $\begin{array}{c}\text { EXPEND_G } \\
\text { OV }\end{array}$ & DEFICIT_GOV & $\begin{array}{c}\text { REVEN_G } \\
\text { OV }\end{array}$ & TIMETAX & RURAL_POP \\
\hline Mean & 4.617647 & 4.674069 & 8.565341 & 27.84955 & -1.81611 & 18.13915 & 216.847 & 36.10472 \\
\hline Median & 4.578004 & 4.609141 & 7.283406 & 27.24283 & -1.98908 & 17.44946 & 201.000 & 33.40000 \\
\hline $\begin{array}{l}\text { Maximu } \\
\mathrm{m}\end{array}$ & 19.49237 & 20.02097 & 99.13157 & 62.25467 & 36.41069 & 38.08376 & 798.000 & 83.23200 \\
\hline $\begin{array}{l}\text { Minimu } \\
\text { m } \\
\text { Std. Dev. }\end{array}$ & $\begin{array}{l}-14.2155 \\
5.118203\end{array}$ & $\begin{array}{l}-13.2343 \\
5.136073\end{array}$ & $\begin{array}{l}-54.753 \\
15.3018\end{array}$ & $\begin{array}{l}4.973677 \\
10.70562\end{array}$ & $\begin{array}{l}-32.0541 \\
3.818241\end{array}$ & $\begin{array}{l}4.098501 \\
5.999487\end{array}$ & $\begin{array}{c}50.000 \\
103.4202\end{array}$ & $\begin{array}{c}1.95900 \\
19.31154\end{array}$ \\
\hline $\begin{array}{l}\text { Skewnes } \\
\text { S }\end{array}$ & 0.039222 & 0.029898 & 1.216317 & 0.184878 & 1.108226 & 0.400314 & 1.425522 & 0.382131 \\
\hline $\begin{array}{l}\text { Kurtosis } \\
\text { Jarque- }\end{array}$ & 4.411487 & 4.627412 & 9.598617 & 2.145407 & 20.94047 & 2.734094 & 6.545427 & 2.462841 \\
\hline Bera & 72.44376 & 96.13667 & 1792.905 & 31.43048 & 11845.52 & 25.79947 & 750.3207 & 31.63301 \\
\hline & $\begin{array}{c}\text { CONTRIB_R } \\
\text { ATE }\end{array}$ & FIXEDCAP & $\begin{array}{c}\text { MANUF_ } \\
\text { VA }\end{array}$ & $\begin{array}{c}\text { COM_BALA } \\
\text { NCE }\end{array}$ & $\begin{array}{c}\text { CORR } \\
\text { E } \\
\text { GDP_R } \\
\text { EG }\end{array}$ & $\begin{array}{l}\text { CORREL } \\
\text { _GDP_W }\end{array}$ & $\begin{array}{c}\text { CORREL_GDPC } \\
\text { _REG }\end{array}$ & $\underset{\text { C_W }}{\text { CORRELGDP }}$ \\
\hline Mean & 39.78356 & 23.25765 & 13.34152 & -3.39623 & 0.586808 & 0.574349 & 0.5875 & 0.576835 \\
\hline Median & 39.35000 & 22.072 & 12.64328 & -1.18423 & 0.697715 & 0.690111 & 0.699833 & 0.687065 \\
\hline $\begin{array}{l}\text { Maximu } \\
\mathrm{m}\end{array}$ & 203.8000 & 81.05174 & 34.86428 & 36.01476 & 0.997908 & 0.979643 & 0.998123 & 0.978238 \\
\hline $\begin{array}{l}\text { Minimu } \\
\text { m } \\
\text { Std. Dev. }\end{array}$ & $\begin{array}{c}7.40000 \\
15.03988\end{array}$ & $\begin{array}{l}6.349849 \\
7.189535\end{array}$ & $\begin{array}{l}2.127626 \\
5.443009\end{array}$ & $\begin{array}{l}-66.6167 \\
13.21422\end{array}$ & $\begin{array}{l}-0.74284 \\
0.358342\end{array}$ & $\begin{array}{l}-0.81907 \\
0.350978\end{array}$ & $\begin{array}{l}-0.76556 \\
0.361694\end{array}$ & $\begin{array}{l}-0.56703 \\
0.346022\end{array}$ \\
\hline Skewnes & & & & & & & & \\
\hline $\mathrm{s}$ & 2.146107 & 2.880315 & 0.600643 & -0.70161 & -1.22475 & -1.25123 & -1.31967 & -1.268 \\
\hline $\begin{array}{l}\text { Kurtosis } \\
\text { Jarque- }\end{array}$ & 20.04797 & 18.70272 & 3.527058 & 5.695423 & 4.080398 & 3.970962 & 4.394819 & 3.930172 \\
\hline Bera & 11203.3 & 10141.31 & 62.38179 & 334.7439 & 259.8135 & 261.1825 & 323.046 & 264.4973 \\
\hline
\end{tabular}

Source: own estimations based on World Bank's data

\section{Appendix 2: Unit Root tests (all variables)}

\begin{tabular}{|c|c|c|c|c|c|c|c|c|c|c|c|c|}
\hline \multirow[b]{2}{*}{ Unit root test: } & \multicolumn{2}{|c|}{ GDP_GAP } & \multicolumn{2}{|c|}{ GDP_CAP_GAP } & \multicolumn{2}{|c|}{ CLAIMS_GOV } & \multicolumn{2}{|c|}{ EXPEND_GOV } & \multicolumn{2}{|c|}{ DEFICIT_GOV } & \multicolumn{2}{|c|}{ REVEN_GOV } \\
\hline & $\begin{array}{c}\text { Statisti } \\
\text { c }\end{array}$ & $\begin{array}{l}\text { Statisti } \\
\text { c }\end{array}$ & $\begin{array}{c}\text { Statisti } \\
\text { c }\end{array}$ & $\begin{array}{c}\text { Statisti } \\
\text { c }\end{array}$ & Statistic & $\begin{array}{l}\text { Statisti } \\
\text { c }\end{array}$ & $\begin{array}{c}\text { Statisti } \\
\text { c }\end{array}$ & $\begin{array}{c}\text { Statisti } \\
\text { c }\end{array}$ & $\begin{array}{c}\text { Statisti } \\
\text { c }\end{array}$ & $\begin{array}{l}\text { Statisti } \\
\text { c }\end{array}$ & $\begin{array}{c}\text { Statisti } \\
\text { c }\end{array}$ & $\begin{array}{l}\text { Statisti } \\
\text { c }\end{array}$ \\
\hline Levin, Lin \& Chu t* & -5.021 & 0.000 & -5.002 & 0.000 & -1.557 & 0.000 & -1.880 & 0.000 & -2.487 & 0.000 & -1.642 & 0.000 \\
\hline $\begin{array}{l}\text { Im, Pesaran and Shin } \\
\text { W-stat }\end{array}$ & -1.528 & 0.000 & -1.514 & 0.000 & 0.000 & 0.208 & -2.453 & 0.007 & -4.106 & 0.000 & -1.759 & 0.039 \\
\hline $\begin{array}{l}\text { ADF - Fisher Chi- } \\
\text { square }\end{array}$ & $\begin{array}{c}645.65 \\
8\end{array}$ & 0.000 & $\begin{array}{c}625.83 \\
5\end{array}$ & 0.000 & 223.527 & 0.007 & $\begin{array}{c}275.65 \\
2\end{array}$ & 0.000 & 322.863 & 0.000 & $\begin{array}{c}252.23 \\
6\end{array}$ & 0.000 \\
\hline $\begin{array}{l}\text { PP - Fisher Chi- } \\
\text { square }\end{array}$ & $\begin{array}{c}675.20 \\
8\end{array}$ & 0.000 & $\begin{array}{c}673.09 \\
3\end{array}$ & 0.000 & 254.617 & 0.000 & $\begin{array}{c}362.76 \\
9\end{array}$ & 0.000 & 439.227 & 0.000 & $\begin{array}{c}340.05 \\
4\end{array}$ & 0.000 \\
\hline Stationary: & \multicolumn{2}{|c|}{ Yes } & \multicolumn{2}{|c|}{ Yes } & \multicolumn{2}{|c|}{ Yes } & \multicolumn{2}{|c|}{ Yes } & \multicolumn{2}{|c|}{ Yes } & \multicolumn{2}{|c|}{ Yes } \\
\hline \multirow[b]{2}{*}{ Unit root test: } & \multicolumn{2}{|c|}{ TIMETAX } & \multicolumn{2}{|c|}{ CONTRIB } & \multicolumn{2}{|c|}{ RURAL_POP } & \multicolumn{2}{|c|}{ FIXED_CAP } & \multicolumn{2}{|c|}{ MANUF_VA } & \multicolumn{2}{|c|}{ COM_BALANCE } \\
\hline & $\begin{array}{c}\text { Statisti } \\
\text { c }\end{array}$ & $\begin{array}{c}\text { Statisti } \\
\text { c }\end{array}$ & $\begin{array}{c}\text { Statisti } \\
\text { c }\end{array}$ & $\begin{array}{c}\text { Statisti } \\
\text { c }\end{array}$ & Statistic & $\begin{array}{c}\text { Statisti } \\
\text { c }\end{array}$ & $\begin{array}{c}\text { Statisti } \\
\text { c }\end{array}$ & $\begin{array}{c}\text { Statisti } \\
\text { c }\end{array}$ & $\begin{array}{l}\text { Statisti } \\
\text { c }\end{array}$ & $\begin{array}{l}\text { Statisti } \\
\text { c }\end{array}$ & $\begin{array}{c}\text { Statisti } \\
\text { c }\end{array}$ & $\begin{array}{c}\text { Statisti } \\
\text { c }\end{array}$ \\
\hline Levin, Lin \& Chu t* & -3.486 & 0.000 & -9.437 & 0.000 & -1.785 & 0.0371 & -17.429 & 0.000 & $\begin{array}{c}- \\
16.4011\end{array}$ & 0.0000 & -15.088 & 0.000 \\
\hline $\begin{array}{l}\text { Im, Pesaran and Shin } \\
\text { W-stat }\end{array}$ & -5.466 & 0.000 & -7.570 & 0.000 & -0.399 & 0.3451 & -1.815 & 0.035 & -1.0764 & 0.1409 & -1.442 & 0.075 \\
\hline $\begin{array}{l}\text { ADF - Fisher Chi- } \\
\text { square }\end{array}$ & $\begin{array}{c}265.99 \\
4\end{array}$ & 0.000 & $\begin{array}{l}239.98 \\
\quad 2\end{array}$ & 0.001 & 297.537 & 0.0000 & 0.000 & 0.000 & $\begin{array}{c}231.083 \\
0\end{array}$ & 0.0025 & $\begin{array}{c}242.19 \\
3\end{array}$ & 0.001 \\
\hline $\begin{array}{l}\text { PP - Fisher Chi- } \\
\text { square }\end{array}$ & $\begin{array}{c}261.56 \\
6\end{array}$ & 0.000 & $\begin{array}{c}288.22 \\
9\end{array}$ & 0.000 & 482.076 & 0.0000 & $\begin{array}{c}284.62 \\
0\end{array}$ & 0.000 & $\begin{array}{c}249.981 \\
0\end{array}$ & 0.0001 & $\begin{array}{c}292.48 \\
3\end{array}$ & 0.000 \\
\hline Stationary: & & es & \multicolumn{2}{|c|}{ Yes } & \multicolumn{2}{|c|}{ Yes } & \multicolumn{2}{|c|}{ Yes } & \multicolumn{2}{|c|}{ Yes } & \multicolumn{2}{|c|}{ Yes } \\
\hline \multirow{2}{*}{ Unit root test: } & \multicolumn{2}{|c|}{$\begin{array}{c}\text { CORREL_GDP_R } \\
\text { EG }\end{array}$} & CORR & L_GDP_W & $\begin{array}{r}\text { CORR } \\
\text { C }\end{array}$ & $\begin{array}{l}\text { EL_GDP } \\
\text { REG }\end{array}$ & CORREI & GDPC & & & & \\
\hline & $\begin{array}{c}\text { Statisti } \\
\text { c }\end{array}$ & $\begin{array}{l}\text { Statisti } \\
\text { c }\end{array}$ & $\begin{array}{c}\text { Statisti } \\
\text { c }\end{array}$ & Statisti & Statistic & $\begin{array}{c}\text { Statisti } \\
\text { c }\end{array}$ & $\begin{array}{c}\text { Statisti } \\
\text { c }\end{array}$ & $\begin{array}{l}\text { Statisti } \\
\text { c }\end{array}$ & & & & \\
\hline Levin, Lin \& Chu $t^{*}$ & -1.449 & 0.000 & -1.535 & 0.000 & -1.410 & 0.000 & -1.688 & 0.000 & & & & \\
\hline $\begin{array}{l}\text { Im, Pesaran and Shin } \\
\text { W-stat }\end{array}$ & -1.353 & 0.088 & 0.000 & 0.190 & -1.441 & 0.075 & 0.000 & 0.183 & & & & \\
\hline $\begin{array}{l}\text { ADF - Fisher Chi- } \\
\text { square }\end{array}$ & $\begin{array}{c}240.36 \\
4\end{array}$ & 0.001 & $\begin{array}{c}222.57 \\
4\end{array}$ & 0.008 & 246.081 & 0.000 & $\begin{array}{c}217.37 \\
4\end{array}$ & 0.014 & & & & \\
\hline $\begin{array}{l}\text { PP - Fisher Chi- } \\
\text { square }\end{array}$ & $\begin{array}{c}256.84 \\
0\end{array}$ & 0.000 & $\begin{array}{c}227.50 \\
4\end{array}$ & 0.004 & 280.185 & 0.000 & $\begin{array}{c}198.34 \\
9\end{array}$ & 0.100 & & & & \\
\hline Stationary: & & es & & & Ye & & & & & & & \\
\hline
\end{tabular}

Source: own estimations based on World Bank's data 
Appendix 3: Kao Residual Cointegration Tests

Panel 1 Kao Residual Cointegration Test (GDP growth rate)

Series: GDP_CAP_GAP CORREL_GDP_REG CORREL_GDP_W

CLAIMS GOV EXPEND GOV DEFICIT GOV REVEN GOV

TIMETAX CONTRIB_RATE RURAL_POP FIXEDCAP MANUF_VA

t-Statistic Prob.

ADF Test

Res. var.

HAC var.

COM_BALANCE

Cointegration

Panel 2 Kao Residual Cointegration Test (GDP per capita growth rate)

Series: GDP_CAP_GAP CORREL_GDPC_REG CORREL_GDPC_W

CLAIMS_GOV EXPEND_GOV DEFICIT_GOV REVEN_GOV

TIMETAX CONTRIB_RATE RURAL_POP FIXEDCAP MANUF_VA

COM_BALANCE

Cointegration

Source: own estimations based on World Bank's data

\section{Appendix 4: VECM Long-run relationship tests}

\begin{tabular}{lccccc}
\multicolumn{1}{c}{ Error Correction Term } & Coefficient & Std. Error & t-Statistic & Prob. & Long-run \\
determination
\end{tabular}

Source: own estimations based on World Bank's data

\begin{tabular}{|c|c|c|c|}
\hline Wald Test Panel 1 & Value Chi-square & Probability & Short-run determination \\
\hline CLAIMS_GOV & 1.635982 & 0.4413 & No \\
\hline EXPEND_GOV & 2.065067 & 0.3561 & No \\
\hline DEFICIT_GOV & 8.492948 & 0.0143 & Yes* \\
\hline REVEN_GOV & 0.431837 & 0.8058 & No \\
\hline TIMETAX & 9.215266 & 0.0100 & Yes* \\
\hline CONTRIB_RATE & 327.6846 & 0.0000 & Yes* \\
\hline RURAL_POP & 6.040882 & 0.0488 & Yes* \\
\hline FIXEDCAP & 2.935752 & 0.2304 & No \\
\hline MANUF_VA & 17.37547 & 0.0002 & Yes* \\
\hline COM_BALANCE & 0.554495 & 0.7579 & No \\
\hline CORREL_GDP_REG & 2.605624 & 0.2718 & No \\
\hline CORREL_GDP_W & 4.689165 & 0.0959 & Yes** \\
\hline
\end{tabular}

Source: own estimations based on World Bank's data

\begin{tabular}{|c|c|c|c|}
\hline Wald Test Panel 2 & Value Chi-square & Probability & Short term determination \\
\hline CLAIMS_GOV & 1.245408 & 0.5365 & No \\
\hline EXPEND_GOV & 2.766747 & 0.2507 & No \\
\hline DEFICIT_GOV & 6.191768 & 0.0452 & Yes* \\
\hline REVEN_GOV & 0.337472 & 0.8447 & No \\
\hline TIMETAX & 6.965529 & 0.0307 & Yes* \\
\hline CONTRIB_RATE & 333.8392 & 0.0000 & Yes* \\
\hline RURAL_POP & 7.366304 & 0.0251 & Yes* \\
\hline FIXEDCAP & 2.532836 & 0.2818 & No \\
\hline MANUF_VA & 16.29751 & 0.0003 & Yes* \\
\hline COM_BALANCE & 0.318446 & 0.8528 & No \\
\hline CORREL_GDP_REG & 1.566036 & 0.4570 & No \\
\hline CORREL_GDP_W & 2.667545 & 0.2635 & No \\
\hline
\end{tabular}

Source: own estimations based on World Bank's data

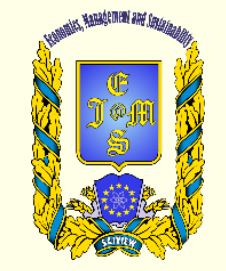

(c) 2016-2021, Economics, Management and Sustainability. All rights reserved.

This open access article is distributed under a Creative Commons Attribution (CC-BY) 4.0 license.

You are free to:

Share - copy and redistribute the material in any medium or format Adapt - remix, transform, and build upon the material for any

purpose, even commercially.

The licensor cannot revoke these freedoms as long as you follow the license terms.

Under the following terms:

Attribution - You must give appropriate credit, provide a link to the license, and indicate if changes were made.

You may do so in any reasonable manner, but not in any way that suggests the licensor endorses you or your use.

No additional restrictions

You may not apply legal terms or technological measures that legally restrict others from doing anything the license permits.

Economics, Management and Sustainability (ISSN: 2520-6303) is published by Scientific Publishing House "CSR",

Poland, EU and Scientific Publishing House "SciView", Poland

Publishing with JEMS ensures:

- Immediate, universal access to your article on publication

- High visibility and discoverability via the JEMS website

- Rapid publication

- Guaranteed legacy preservation of your article

- Discounts and waivers for authors in developing regions

Submit your manuscript to a JEMS at http://jems.sciview.net or submit.jems@sciview.net

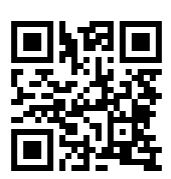

